\title{
A Rapid PCR-Based Method for the Detection of Magnaporthe oryzae from Infected Perennial Ryegrass
}

\author{
Philip F. Harmon, Department of Botany and Plant Pathology, Larry D. Dunkle, Department of Botany and Plant \\ Pathology and U.S. Department of Agriculture, Agricultural Research Service, and Richard Latin, Department of \\ Botany and Plant Pathology, Purdue University, West Lafayette IN 47907
}

\begin{abstract}
Harmon, P. F., Dunkle, L. D., and Latin, R. 2003. A rapid PCR-based method for the detection of Magnaporthe oryzae from infected perennial ryegrass. Plant Dis. 87:1072-1076.

Gray leaf spot caused by Magnaporthe oryzae is a serious disease of perennial ryegrass in the midwestern United States. Symptoms of gray leaf spot can be confused with those caused by other fungal diseases that also are common during periods of high temperatures and ample moisture. Because turf managers must select appropriate fungicides for remedial treatment, accurate and timely identification of the pathogen is essential for efficient and effective disease management. We developed and evaluated a polymerase chain reaction (PCR)-based method to detect $M$. oryzae in infected perennial ryegrass tissue. The method utilizes a commercially available kit that is used for isolation and amplification of plant DNA from leaf tissue. The kit protocol was modified and found to be reliable for the extraction of $M$. oryzae DNA from infected perennial ryegrass. Primers were designed to amplify a 687-bp fragment of the Pot2 transposon that is found in multiple copies in the genome of the pathogen. The protocol amplified amounts of purified DNA as low as $5 \mathrm{pg}$ and consistently and specifically detected $M$. oryzae in single diseased leaf blades as well as in field samples of infected perennial ryegrass. The total time required for detection was approximately 4 to $8 \mathrm{~h}$.
\end{abstract}

The fungus Magnaporthe oryzae Couch (anamorph = Pyricularia oryzae Cavara) (previously known as Magnaporthe grisea (Herbert) Barr) (4) causes gray leaf spot disease of perennial ryegrass (Lolium perenne L.) (12). In recent years, this disease has become a serious but sporadic problem for turfgrass managers in the mid-Atlantic and midwestern United States $(9,12,16$, 20,22). The disease can cause blighting and death of large areas of turf and occurs most frequently on perennial ryegrass managed for athletic fields and golf courses.

Diagnosis of gray leaf spot and identification of $M$. oryzae in diseased perennial ryegrass samples can be difficult and timeconsuming, depending on clinical expertise, the condition of the sample, the extent of symptoms, and the concomitant presence of other fungal pathogens. With extended periods of favorable environmental conditions, leaf spot symptoms may be short-lived, because infected leaf blades rapidly collapse and become necrotic $(12,19)$. Leaf spots and blight also are associated with other summer diseases that

Corresponding author: R. Latin

E-mail: rlatin@purdue.edu

Purdue University Agricultural Research Programs Journal Series Article No. 16978.

Accepted for publication 3 April 2003.

Publication no. D-2003-0616-06R

(c) 2003 The American Phytopathological Society result in little or no lasting turf damage. Because the summer leaf spot diseases of perennial ryegrass require different management strategies, an accurate and timely diagnosis is important for effective and efficient disease management. Current diagnostic protocols for gray leaf spot may include incubation of turf specimens for at least $24 \mathrm{~h}$ and microscopic examination of leaves and leaf tissues for the presence of characteristic conidia produced by $M$. oryzae. Therefore, numerous factors can reduce the reliability and timeliness of the diagnosis by these conventional methods.

Polymerase chain reaction (PCR) is a common molecular procedure that has been developed to detect or identify a number of plant pathogens $(1-3,5,11,13-$ 15,17). Implementation of these methods varies, but an increasing number of diagnostic laboratories have the ability and resources to utilize PCR methods for disease identification. PCR-based methods are very reliable, timely, and species-specific when appropriate oligonucleotides are selected as primers. They are especially useful for detecting pathogens that incite sporadic disease outbreaks or may be easily confused with less damaging pathogens at the start of the epidemic.

In this research, we designed primers to PCR-amplify regions of the Pot 2 transposon (EMBL Accession No. Z33638). Pot2 has been reported in and is believed to be present only in isolates of $M$. grisea and $M$. oryzae from various hosts $(7,8,10)$. Significantly, the Pot 2 transposon has been found in all of approximately 50 perennial ryegrass isolates of $M$. oryzae tested (M. Farman, personal communication) and, therefore, is more specific than other potentially useful sequences, such as the internal transcribed spacer region of rDNA. Pot2 is believed to have originated in an ancestor of these fungi, before the evolution of host specificity, and was estimated to be present in 100 copies in the $M$. oryzae genome (10). A recent study of perennial ryegrass isolates of $M$. oryzae based on repetitive probes, including Pot2, reported that the pathogen population that infects perennial ryegrass has limited genetic diversity (6). The presence of multiple copies of the Pot 2 sequence in the genome facilitates PCR detection of the pathogen in infected tissue.

The main objective of this research was to develop an accurate and rapid method to detect $M$. oryzae in symptomatic perennial ryegrass samples. For this protocol to be successful, the PCR primers had to selectively amplify a region of the Pot 2 transposon in isolates of $M$. oryzae from perennial ryegrass, without amplifying DNA from perennial ryegrass itself or other pathogens. The protocol represents a modification of a commercially available kit for plant DNA isolation and detects the pathogen in less than $8 \mathrm{~h}$.

\section{MATERIALS AND METHODS}

Isolation and maintenance of fungal cultures. Fungi used in this study (Tables 1 and 2) were isolated from perennial ryegrass turf in Indiana during the growing seasons of 1999 through 2002 unless otherwise stated. Cultures were maintained on V8 juice agar (200 $\mathrm{ml}$ of V8 juice [Campbell Soup Company, Camden, NJ], $3 \mathrm{~g}$ of $\mathrm{CaCO}_{2}$, and $15 \mathrm{~g}$ of agar in 1 liter of media) or potato dextrose agar (PDA) (Difco, Detroit, MI) and stored desiccated on filter paper at $4^{\circ} \mathrm{C}$ as previously described for $M$. oryzae (21). Isolates were obtained by suspending symptomatic perennial ryegrass leaf blades with double-sided tape attached to the lids of V8 juice agar culture dishes. The lids were moved to fresh V8 juice agar dishes every $24 \mathrm{~h}$ for 3 days. Exposed culture dishes were covered with unused sterile lids and incubated at $23^{\circ} \mathrm{C}$ under constant fluorescent light. Suspect colonies based on their gray color, morphology, and growth rate were transferred to fresh culture dishes. The identity of 
these colonies was confirmed microscopically by the presence of pale brown to hyaline, pyriform, and mostly three-celled sympodioconidia characteristic of $M$. oryzae (23). Other perennial ryegrass pathogens were commonly found in turf samples with gray leaf spot symptoms and were isolated and cultured by the same procedure or directly on agar after surfacesterilization of the leaf tissue for $2 \mathrm{~min}$ in a $10 \%$ bleach solution $\left(0.525 \% \mathrm{NaClO}_{4}\right)$.

For DNA extraction, cultures were transferred from storage onto V8 juice agar. Three to five 2-mm-diameter agar plugs from colonies of each isolate were transferred to flasks containing $100 \mathrm{ml}$ of sterile potato dextrose broth. The cultures were incubated on a rotary shaker $(150 \mathrm{rpm})$ in darkness at $25^{\circ} \mathrm{C}$ for 5 days. Mycelium was harvested by filtration through Whatman No. 2 filter paper, rinsed with sterile water, and blotted dry with a paper towel. The mycelium was then frozen in liquid nitrogen and stored at $-80^{\circ} \mathrm{C}$.

Inoculation and incubation of perennial ryegrass. Lesions were produced on 2-week-old perennial ryegrass cv. Legacy II inoculated with $M$. oryzae isolate IN0025. Conidia from an actively growing colony of the fungus were deposited directly onto leaf blades, and the inoculated plants were incubated in a near moisturesaturated environment in plastic bags at $23^{\circ} \mathrm{C}$ for $72 \mathrm{~h}$.

DNA extraction. Genomic DNA was isolated and purified from $M$. oryzae isolate IN0025 and isolates of other turfgrass pathogens, IN0027, IN0028, IN0102, IN0104, IN0201, IN0202, and IN0206, described in Table 2. Mycelium of each isolate was ground in liquid nitrogen and suspended in $0.4 \mathrm{ml}$ of phenol and $0.8 \mathrm{ml}$ of fungal genomic DNA extraction buffer (100 mM LiCl, $10 \mathrm{mM}$ EDTA, $10 \mathrm{mM}$ Tris, $\mathrm{pH} 8.0,0.5 \%$ sodium dodecyl sulfate (SDS), and $0.1 \% \quad \beta$-mercaptoethanol). Suspensions were incubated at $60^{\circ} \mathrm{C}$ for 5 min. Tubes were gently agitated, allowed to cool, and $0.4 \mathrm{ml}$ of chloroform/isoamyl alcohol (24:1, vol/vol) was added. Tubes were centrifuged at $16,000 \mathrm{RCF}$ for 10 $\mathrm{min}$, and $0.7 \mathrm{ml}$ of the upper phase was extracted with an equal volume of chloroform/isoamyl alcohol (24:1, vol/vol). DNA was precipitated from the upper phase with $1.0 \mathrm{ml}$ of cold ethanol containing $150 \mathrm{mM}$ sodium acetate. The pellet was allowed to dry for $5 \mathrm{~min}$, then dissolved in $0.5 \mathrm{ml}$ of TE buffer (1 mM EDTA, $10 \mathrm{mM}$ Tris, $\mathrm{pH}$ 8.0). After RNase treatment $(50 \mu \mathrm{g})$, phenol/chloroform extraction and ethanol precipitation were performed to obtain fungal genomic DNA. The pellet was dissolved in $0.1 \mathrm{ml}$ of TE buffer ( $\mathrm{pH} \mathrm{8.0)}$ ), and DNA was quantified with a spectrophotometer (18). Final concentration of each sample was adjusted to $50 \mathrm{ng} / \mu \mathrm{l}$. A serial dilution (50 ng, $5 \mathrm{ng}, 0.5 \mathrm{ng}, 50 \mathrm{pg}$, and $5 \mathrm{pg} / \mu \mathrm{l})$ of the genomic DNA isolated from $M$. oryzae isolate IN0025 was used to establish a detection limit for the protocol.

DNA from symptomatic perennial ryegrass leaves, both inoculated and naturally occurring, was isolated with the Extract-NAmp kit (02-03 catalog no. XNA-P2, Sigma Chemical Co., St. Louis, MO). The recommended protocol was modified significantly because it was ineffective for isolating fungal DNA from infected leaf blades. Infected leaf blades were placed in 1.5-ml Eppendorf tubes and sufficient extract solution (provided in the kit) was added to cover the plant material $(100 \mu \mathrm{l})$. After incubation at $95^{\circ} \mathrm{C}$ for $10 \mathrm{~min}$, an equal volume of dilution solution (provided in the kit) was added, and the sample was homogenized in the Eppendorf tube with a polypropylene pestle. The sample extract was placed on ice, and $5 \mu$ was diluted 10 -fold in sterile distilled water.

Isolates of $M$. oryzae and $M$. grisea listed in Tables 1 and 2 were tested for the presence of Pot2. Desiccated filter paper sections $\left(9 \mathrm{~mm}^{2}\right)$ of the stored isolates were processed with the Extract-N-Amp kit in the same manner as symptomatic perennial ryegrass leaf blades as described above.

PCR amplification and detection of diagnostic amplicon. PCR primers were designed to amplify a 687-bp region of the Pot 2 transposon. Primers used were pfh $2 \mathrm{a}$
(5'-CGTCACACGTTCTTCAACC-3') and pfh2b (5'-CGTTTCACGCTTCTCCG-3'). PCR was performed in a $50-\mu$ reaction mixture with DNA Taq polymerase (Promega, Madison, WI) and purified genomic DNA from eight fungal isolates above. PCR was performed for all symptomatic plant samples in a $20-\mu$ reaction mixture with the Extract-N-Amp kit in a DNA thermal cycler (Model 480, Perkin Elmer Cetus, Norwalk, CT).

The 50- $\mu$ l reaction mixtures consisted of $0.5 \mu \mathrm{l}$ of DNA Taq polymerase (2.5 U), 5 $\mu \mathrm{l}$ of $10 \times$ polymerase buffer, $3 \mu \mathrm{l}$ of 25 $\mathrm{mM} \mathrm{MgCl} 2,1 \mu \mathrm{l}$ of $10 \mathrm{mM}$ dNTP, $2 \mu \mathrm{l}$ of $20 \mathrm{pmol} / \mu \mathrm{l}$ of each primer, and $1 \mu \mathrm{l}$ of the template (extracted genomic DNA at 50 $\mathrm{ng} / \mu \mathrm{l}$ ) in a total volume of $50 \mu \mathrm{l}$.

The reaction mixtures used with the Extract-N-Amp kit consisted of $4 \mu \mathrm{l}$ of the diluted sample extract, $10 \mu \mathrm{l}$ of $2 \times$ PCR mix (kit), and $3 \mu \mathrm{l}$ of $20 \mathrm{pmol} / \mu \mathrm{l}$ of each primer in a total volume of $20 \mu \mathrm{l}$.

The PCR program consisted of an initial denaturation of $2 \mathrm{~min}$ at $94^{\circ} \mathrm{C}$ followed by 30 cycles of $45 \mathrm{~s}$ of denaturation at $94^{\circ} \mathrm{C}$, $45 \mathrm{~s}$ of annealing at $55^{\circ} \mathrm{C}$, and $45 \mathrm{~s}$ of extension at $72^{\circ} \mathrm{C}$. Final extension was 10 min at $72^{\circ} \mathrm{C}$. The amplification products were subjected to electrophoresis in a $1 \%$ agarose gel and stained for $10 \mathrm{~min}$ in an ethidium bromide solution $(10 \mu \mathrm{g} / \mathrm{ml})$. The

Table 1. Collection information for Magnaporthe oryzae isolates tested for the presence of Pot2

\begin{tabular}{llcl}
\hline Isolate no. & Host species & Date collected & \multicolumn{1}{c}{ Origin $^{\text {a }}$} \\
\hline IN9931 & Lolium perenne & $8 / 23 / 99$ & Lebanon, IN \\
IN9940 & Lolium perenne & $9 / 2 / 99$ & West Lafayette, IN \\
IN0024 & Lolium perenne & $8 / 19 / 00$ & Rensselaer, IN \\
IN0025 & Lolium perenne & $8 / 21 / 00$ & West Lafayette, IN \\
IN0029 & Lolium perenne & $9 / 7 / 00$ & Franklin, IN \\
IN0033 & Lolium perenne & $9 / 15 / 00$ & Bloomington, IN \\
IN0036 & Lolium perenne & $9 / 29 / 00$ & Crawfordsville, IN \\
IN0037 & Lolium perenne & $9 / 29 / 00$ & Johnson, IN \\
IN0106 & Lolium perenne & Bloomington, IN \\
IN0107 & Lolium perenne & $9 / 13 / 01$ & Franklin, IN \\
IN0209 & Lolium perenne & $9 / 17 / 01$ & Bloomington, IN \\
IN0210 & Lolium perenne & Bloomington, IN \\
IN0211 & Lolium perenne & $8 / 28 / 02$ & Lebanon, IN \\
IN0212 & Lolium perenne & $9 / 3 / 02$ & Indianapolis, IN \\
IN0213 & Lolium perenne & $9 / 3 / 02$ & Bloomington, IN \\
IN0214 & Lolium perenne & $9 / 11 / 02$ & Indianapolis, IN \\
IN0215 & Lolium perenne & $9 / 30 / 02$ & Bloomington, IN \\
IN0216 & Lolium perenne & $10 / 1 / 02$ & Crawfordsville, IN \\
IN17 & Oryza sativa & 1986 & India \\
GUY11 & Oryza sativa & 1978 & Guyana \\
\hline
\end{tabular}

a Isolates with the same origin and collected in the same year were collected from different golf courses or athletic fields.

Table 2. Fungal isolates, other than Magnaporthe oryzae, tested for the presence of Pot2

\begin{tabular}{lllcl}
\hline $\begin{array}{l}\text { Isolate } \\
\text { no. }\end{array}$ & \multicolumn{1}{c}{ Fungal species } & \multicolumn{1}{c}{ Host species } & $\begin{array}{c}\text { Date } \\
\text { collected }\end{array}$ & Origin \\
\hline IN0027 & Leptosphaerulina trifolii & Lolium perenne & $8 / 19 / 02$ & Rensselaer, IN \\
IN0028 & Curvularia lunata & Lolium perenne & $8 / 19 / 02$ & Rensselaer, IN \\
IN0102 & Sclerotinia homoeocarpa & Lolium perenne & $5 / 21 / 01$ & West Lafayette, IN \\
IN0104 & Rhizoctonia solani & Lolium perenne & $7 / 11 / 01$ & West Lafayette, IN \\
IN0201 & Laetisaria fuciformis & Lolium perenne & $3 / 26 / 02$ & West Lafayette, IN \\
IN0202 & Bipolaris sorokiniana & Lolium perenne & 2001 & Bloomington, IN \\
IN0206 & Colletotrichum graminicola & Agrostis palustris & $6 / 5 / 02$ & Bloomington, IN \\
IN6 & Magnaporthe grisea & Digitaria sanguinalis & Unknown & India \\
US43 & Magnaporthe grisea & Digitaria sp. & 1991 & United States \\
\hline
\end{tabular}


gel was illuminated, and DNA bands were visualized with UV light. Gel images were obtained with an Eagle Eye electronic photo imaging system (Stratagene, La Jolla, CA). Images were digitized with a flatbed scanner and Adobe Photoshop 6.0.1 (Adobe Systems Incorporated, San Jose, CA).

\section{RESULTS}

To establish the sensitivity and selectivity of this detection method, we performed PCR with genomic DNA samples obtained from mycelia of fungal isolates as described in the Materials and Methods section. The selected primers amplified a 687bp segment from genomic DNA isolated from M. oryzae isolate IN0025. The detection limit was determined to be between 5 and $50 \mathrm{pg}$ of DNA (Fig. 1). In some experiments, a very faint band was visible when $5 \mathrm{pg}$ of template was amplified. The DNA isolated from seven other common fungal foliar pathogens of perennial ryegrass was tested with the same PCR protocol (50 ng of template DNA) in 50- $\mu$ reactions. The specificity of the primers and the detection procedure were documented by the absence of amplified products from any of the other fungi tested (Fig. 2).

The diagnostic 687-bp amplicon from M. oryzae was detected in each of the 10 symptomatic perennial ryegrass leaf blades analyzed (Fig. 3, lanes 2 to 11) and when only a single symptomatic leaf blade was processed together with nine uninoculated (healthy) leaf blades in one sample (Fig. 3, lane 12). The diagnostic amplicon was not detected from a sample that was inoculated

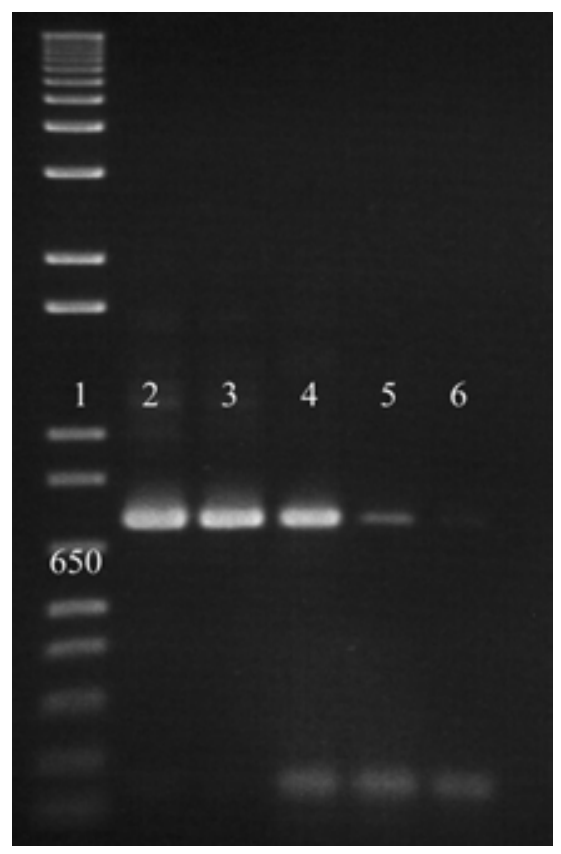

Fig. 1. The 687-bp polymerase chain reaction (PCR) product amplified from dilutions of template DNA from Magnaporthe oryzae. Quantities of DNA were $50 \mathrm{ng}, 5 \mathrm{ng}, 0.5 \mathrm{ng}$, $50 \mathrm{pg}$, and $5 \mathrm{pg}$ (lanes 2-6, respectively). A $1-\mathrm{kb}+$ ladder (Gibco, Carlsbad, CA) is shown in lane 1. and incubated in 1999 and then dried and stored at $23^{\circ} \mathrm{C}$ (Fig. 3, lane 13). The 10 symptomatic leaf blades were imaged to show the extent of symptom expression and to illustrate the small amount of plant material required for the procedure (Fig. 4). The detection protocol also was performed on two symptomatic leaf blades selected from two samples of perennial ryegrass turf collected from the fairways of different golf courses in southern Indiana where gray leaf spot outbreaks were suspected. The only band visible for each sample was a 687-bp band (data not shown). Subsequent isolations from perennial ryegrass in each sample confirmed the presence of the gray leaf spot pathogen. Nonsymptomatic perennial ryegrass leaf blades yielded no bands in any test of the protocol.

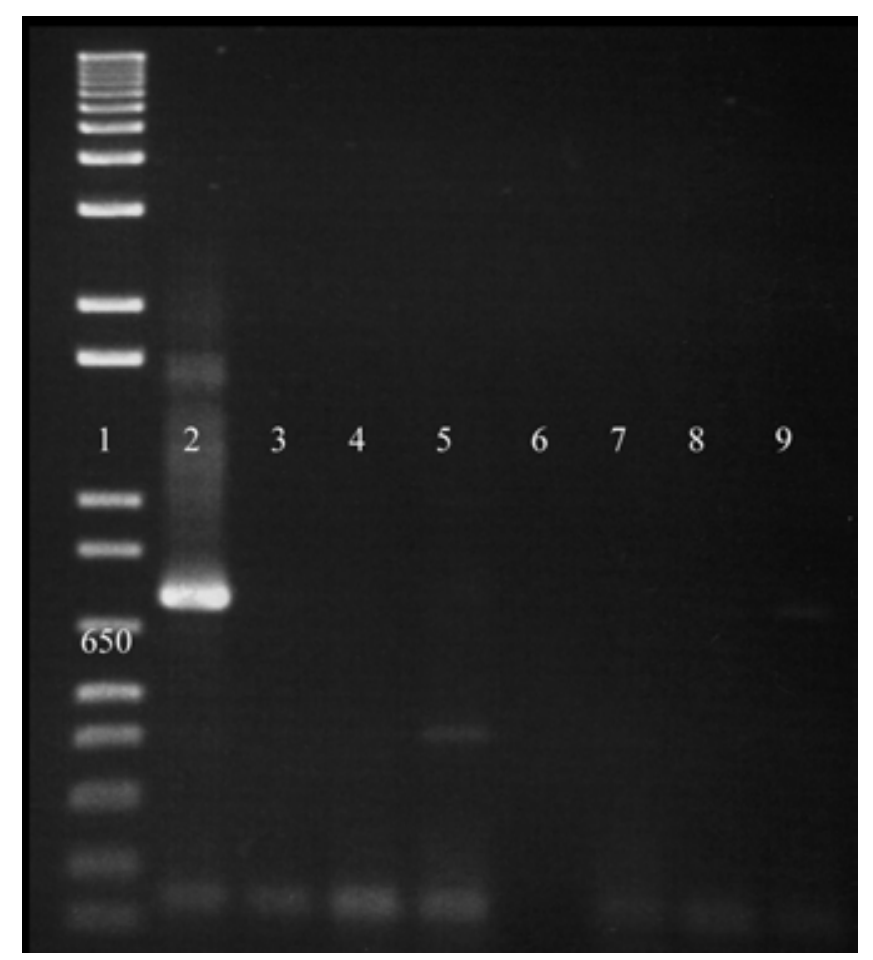

Fig. 2. Polymerase chain reaction (PCR) product (687 bp) amplified from DNA of Magnaporthe oryzae isolate IN0025 (lane 2). Primers were developed to detect the presence of the Pot2 transposon. No PCR product was amplified from DNA of other fungi tested in lanes 3-9 (Bipolaris sorokiniana, Sclerotinia homoeocarpa, Leptosphaerulina trifolii, Rhizoctonia solani, Curvularia lunata, Laetisaria fuciformis, and Colletotrichum graminicola, respectively). A 1-kb+ ladder (Gibco, Carlsbad, CA) is shown in lane 1.

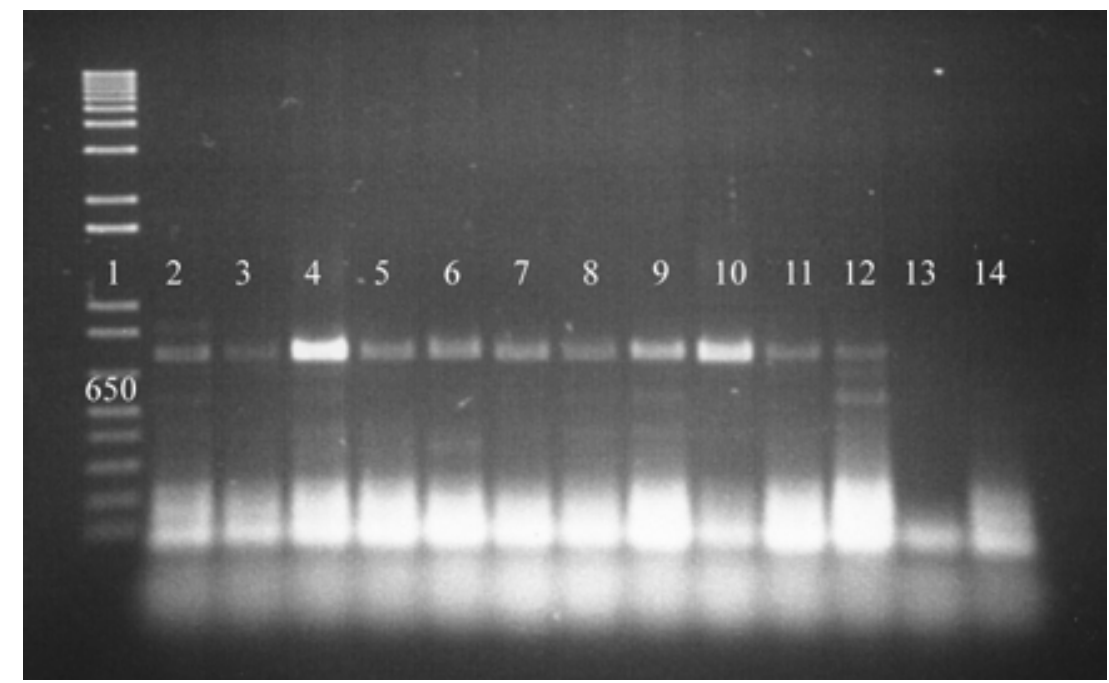

Fig. 3. Detection of Magnaporthe oryzae from 10 inoculated and symptomatic leaf blades of varying sizes (lanes 2-11). One symptomatic leaf blade and nine uninoculated (healthy) leaf blades were processed in one sample (lane 12). A sample of dry, M. oryzae-infested, perennial ryegrass residue from 1999 and a sample of uninoculated (healthy) perennial ryegrass were also processed (lanes 13 and 14, respectively). A 1-kb+ ladder (Gibco, Carlsbad, CA) is shown in lane 1. 
Two isolates of $M$. grisea isolated from a Digitaria sp., two isolates of $M$. oryzae isolated from rice, and 18 Indiana $M$. oryzae isolates isolated from perennial ryegrass were tested for the presence of Pot2. All M. oryzae isolates and the two $M$. grisea isolates produced the diagnostic amplicon (Fig. 5).

\section{DISCUSSION}

Pot 2 has only been reported in isolates of M. oryzae and M. grisea (10). Pot2 is an inverse repeat transposon that shares general structural features with a group of transposons, including Fot1, Tc1, Tcb1, $\mathrm{Hb} 1$, and Mariner (10). Fot1 is the only element that shows homology to Pot2, and only at the predicted amino acid level (10). The predicted amino acid sequence of Pot 2 was reported to have $39.3 \%$ homology with that of Fot1. The most conserved region was reported in the middle of the ORF from amino acid 160 to 380 (10). The primer pair chosen for this protocol amplified a 687-bp region from base pair 1055 to 1741 of the total 1,861 bp (EMBL Accession No. Z33638). Although related transposons have been observed in other fungi, no sequence similarity has been reported. The primer pair was expected to amplify only DNA from $M$. oryzae and $M$. grisea.

The specificity of the PCR primers was tested with perennial ryegrass and isolates of $M$. oryzae, $M$. grisea, and some other pathogens capable of producing leaf spot symptoms. The primers and method were shown to be specific for $M$. grisea and $M$. oryzae. The Pot 2 transposon occurs in

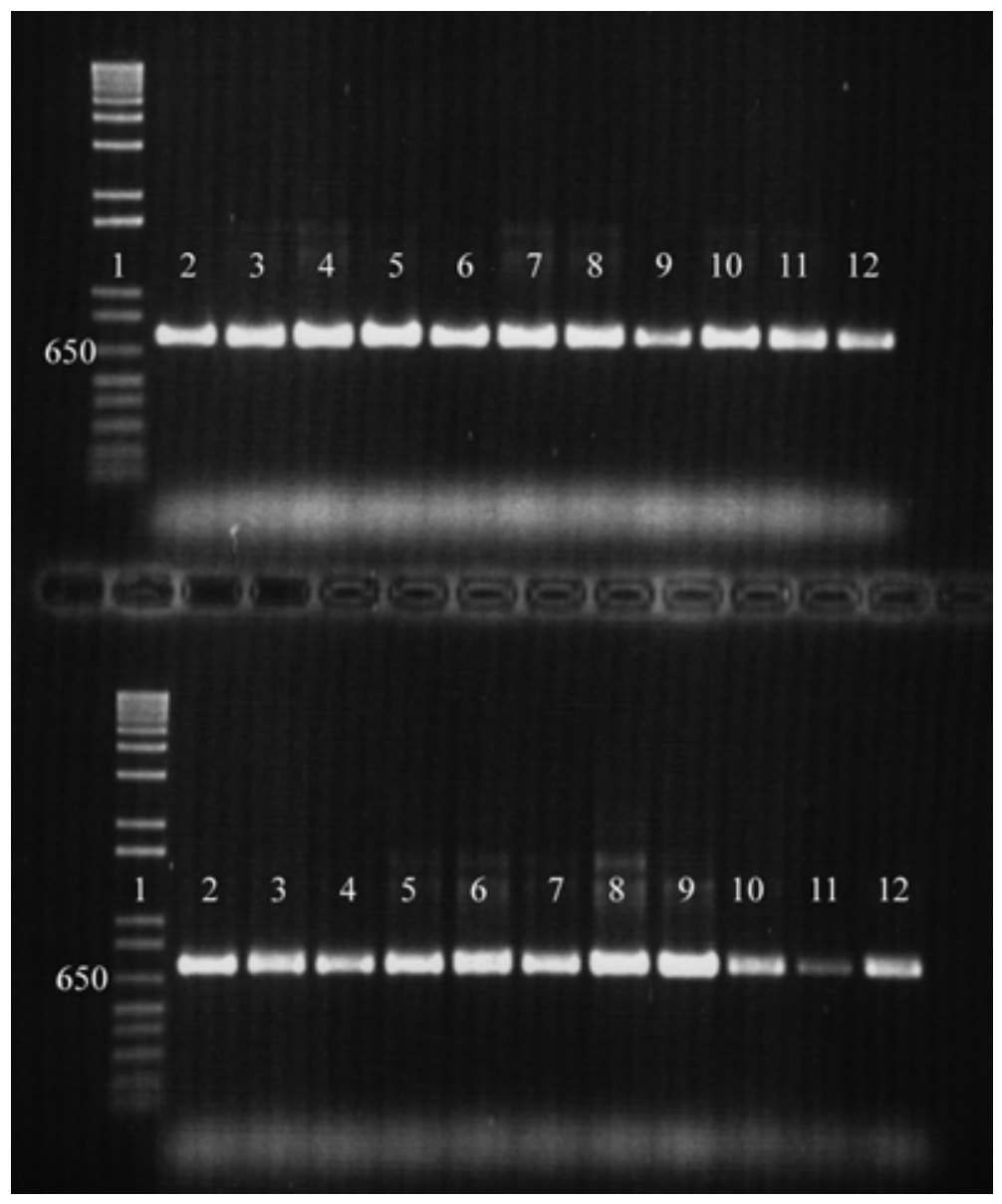

Fig. 5. PCR-based assay for the presence of Pot 2 in 20 isolates of Magnaporthe oryzae and 2 isolates of $M$. grisea. Isolates were tested in the order listed in Table 1 (top, lanes 2-12, and bottom, lanes 29), then Table 2 (bottom, lanes 11 and 12). The expected 687-bp amplicon was detected for all 24 isolates. A 1-kb+ ladder (Gibco, Carlsbad, CA) is shown in lane 1 (top and bottom).

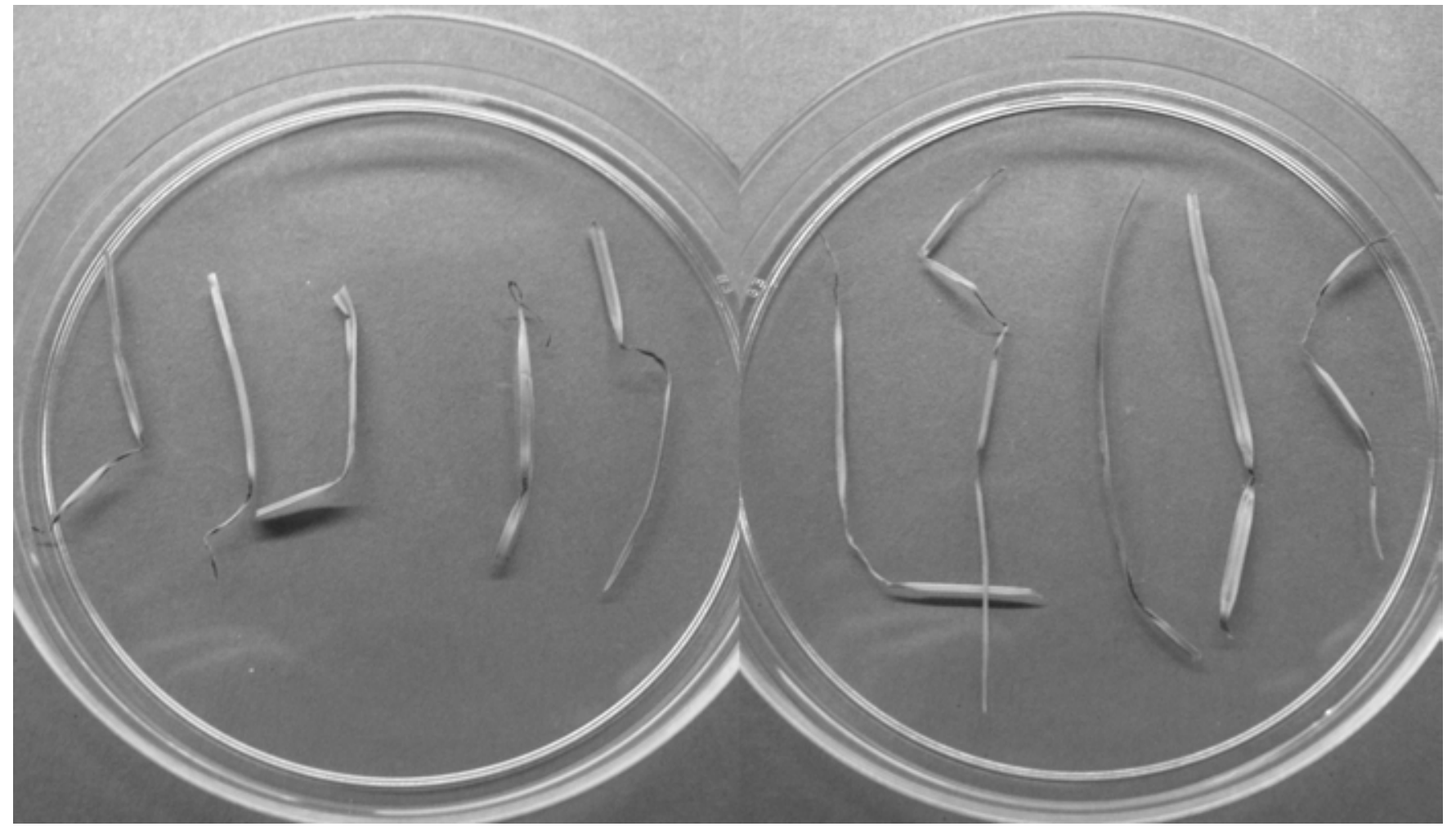

Fig. 4. Magnaporthe oryzae (isolate IN0025) infected perennial ryegrass leaf blades. These 10 leaf blades were used for PCR-based detection of the pathogen (Fig. 3, lanes 2-11). 
multiple copies throughout the genome of $M$. oryzae (10), which enhances the probability of amplification and detection. The limit of detection of purified DNA was found to be between 5 and $50 \mathrm{pg}$. The ability to detect a relatively small amount of DNA enhances the efficiency of the procedure and increases the likelihood of successful detection.

Reliability of the protocol was tested to gauge the number of repetitions that might be required for reliable detection. Symptomatic leaves used for the efficiency assay were produced through inoculation of perennial ryegrass with conidia of $M$. oryzae isolate IN0025 and incubated for $72 \mathrm{~h}$ in a near moisture-saturated environment. Individual leaf lesions were quite small (Fig. 4). In this assay, the protocol was shown to be reliable and sensitive for detection of $M$. oryzae from individual symptomatic leaf blades. The pathogen also was detected from naturally infected turfgrass samples collected from two golf course fairways. The pathogen could not be detected from symptomatic perennial ryegrass leaf blades that were dried and stored at $23^{\circ} \mathrm{C}$ for an extended period of more than 3 years. This suggests that symptomatic leaf blades should be processed fresh without drying or storing the plant material for long periods of time.

Modification of the manufacturer's recommended protocol for the Extract-NAmp kit by including a homogenization step after incubation greatly increased the efficiency of detection. Dilution of the sample extract 10-fold with sterile distilled water rather than with a 1:1 extract/dilute solution (as stated in the manufacturer's protocol) was crucial for detection of the fungal DNA. Repeated attempts failed to amplify target DNA from diseased plant material when the sample was diluted with the 1:1 solution. Detection was unreliable when the sample extract was used directly in the PCR mix. The 10-fold dilution with water consistently yielded more PCR product. When DNA from $M$. oryzae was diluted with the 1:1 solution and added to the PCR reaction, amplification was inhibited (data not shown). Thus, one of the reagents in the kit apparently inhibited amplification of the fungal DNA. Since neither the composition nor the concentrations of the reagents are known, further investigation was not pursued.

The protocol required approximately 15 min for sample preparation, $3 \mathrm{~h}$ for the PCR reaction, and $45 \mathrm{~min}$ for electrophoresis, staining, and imaging the gel. Thus, a 4-h completion time for identification of the pathogen from a single lesion was possible. Using conventional methods, detection of the pathogen in a sample of infected turf may require incubation for 24 to $48 \mathrm{~h}$, microscopic observation of lesions, and possibly isolation of the fungus onto an agar medium. The equipment required for the PCR-based method included the Extract-N-Amp kit, polypropylene homogenization pestles that fit 1.5-ml Eppendorf tubes, plus the equipment needed for PCR reaction, electrophoresis, and detecting the resulting product on an agarose gel. Multiple symptomatic leaf blades can be processed in a single PCR reaction, or individual leaf blades can be processed in multiple reactions in one thermocycler run. In this study, only leaf tissue was used for detection. The cost of an individual sample was not estimated, but the importance of this disease and expense of remedial fungicide treatments justify the costs associated with an accurate and timely method of detection.

Current methods for identifying plant pathogens in high-throughput diagnostic laboratories often involve time-consuming and costly identification following isolation of pathogens. For diagnostic labs to meet increasing demands for accurate and timely diagnosis, new tools for identification must be explored. Knowledge of the nucleotide sequence of many plant pathogens or of species-specific genes has facilitated the adaptation of molecular genetic techniques for detection. PCR is a valuable tool for diagnosis and undoubtedly will become increasingly important for the prompt, accurate diagnosis of pathogens as the technology becomes less expensive, more portable, more user-friendly, and more broadly applicable.

\section{ACKNOWLEDGMENTS}

We thank W.-B. Shim, M. Farman, and J.-R. Xu for their advice and cooperation on this project, and C. Lapaire and M. McClenning for their technical assistance.

\section{LITERATURE CITED}

1. Barros, T. S. L., Davis, R. E., Resende, R. O., and Dally, E. L. 2001. Design of a polymerase chain reaction for specific detection of corn stunt spiroplasma. Plant Dis. 85:475-480.

2. Beretta, M. J. G., Barthe, G. A., Ceccardi, T. L., Lee, R. F., and Derrick, K. S. 1997. A survey for strains of Xylella fastidiosa in citrus affected by citrus variegated chlorosis and citrus blight in Brazil. Plant Dis. 81:1196-1198.

3. Chiocchetti, A., Bernardo, I., Daboussi, M.-J., Garibaldi, A., Gullino, M. L., Langin, T., and Migheli, Q. 1999. Detection of Fusarium oxysporum f. sp. dianthi in carnation tissue by PCR amplification of transposon insertions. Phytopathology 89:1169-1175.

4. Couch, B. C., and Kohn, L. M. 2002. A multilocus gene genealogy concordant with host preference indicates segregation of a new species, Magnaporthe oryzae, from M. grisea. Mycologia 94:683-693.

5. Errampalli, D., Saunders, J., and Cullen, D. 2001. A PCR-based method for detection of potato pathogen, Helminthosporium solani, in silver scurf infected tuber tissue and soils. J. Microbiol. Methods 44:59-68.

6. Farman, M. L. 2002. Pyricularia grisea isolates causing gray leaf spot on perennial rye- grass (Lolium perenne) in the United States: Relationship to $P$. grisea isolates from other host plants. Phytopathology 92:245-254.

7. Farman, M. L., Satoru, T., and Leong, S. A. 1996. The Magnaporthe grisea DNA fingerprinting probe MGR586 contains the $3^{\prime}$ end of an inverted repeat transposon. Mol. Gen. Genet. 251:675-681.

8. George, M. L. C., Nelson, R. J., Zeigler, R. S., and Leung, H. 1998. Rapid population analysis of Magnaporthe grisea by using rep-PCR and endogenous repetitive DNA sequences. Phytopathology 88:223-229.

9. Harmon, P., Rane, K., Ruhl, G., and Latin, R. 2000. First report of gray leaf spot on perennial ryegrass in Indiana. Plant Dis. 84:492.

10. Kachroo, P., Leong, S. A., and Chattoo, B. B. 1994. Pot2, an inverted repeat transposon from the rice blast fungus Magnaporthe grisea. Mol. Gen. Genet. 245:339-348.

11. Kerkoud, M., Manceau, C., and Paulin, J. P. 2002. Rapid diagnosis of Pseudomonas syringae pv. papulans, the causal agent of blister spot of apple, by polymerase chain reaction using specifically designed $h r p L$ gene primers. Phytopathology 92:1077-1083.

12. Landschoot, P. J., and Hoyland, B. F. 1992. Gray leaf spot of perennial ryegrass turf in Pennsylvania. Plant Dis. 76:1280-1282.

13. Larsen, R. C., Hollingsworth, C. R., Vandemark, G. J., Gritsenko, M. A., and Gray, F. A. 2002. A rapid method using PCR-based SCAR markers for the detection and identification of Phoma sclerotioides: The cause of brown root rot disease of alfalfa. Plant Dis. 86:928-932.

14. Minsavage, G. V., Thompson, C. M., Hopkins, D. L., Leite, R. M. V. B. C., and Stall, R. E. 1994. Development of a polymerase chain reaction protocol for detection of Xylella fastidiosa in plant tissue. Phytopathology 84:456-461.

15. Oliveira, A. C., and Vallim, M. A. 2002 Quantification of Xylella fastidiosa from citrus trees by real-time polymerase chain reaction assay. Phytopathology 92:1048-1054.

16. Pedersen, D. K., Kane, R. T., and Wilkinson, H. T. 2000. First report of gray leaf spot caused by Pyricularia grisea on Lolium perenne in Illinois. Plant Dis. 84:1151.

17. Pooler, M. R., and Hartung, J. S. 1995. Specific PCR detection and identification of $X y$ lella fastidiosa strains causing citrus variegated chlorosis. Curr. Microbiol. 31:377-381.

18. Sambrook, J., Fritsch, E. F., and Maniatis, T. 1989. Molecular Cloning: A Laboratory Manual. 2nd ed. Cold Spring Harbor Laboratory Press, Cold Spring Harbor, NY.

19. Trevathan, L. E. 1982. Response of ryegrass plant introductions to artificial inoculation with Pyricularia grisea under greenhouse conditions. Plant Dis. 66:696-697.

20. Uddin, W., Soika, M. D., Moorman, F. E., and Viji, G. 1999. A serious outbreak of blast disease (gray leaf spot) of perennial ryegrass in golf course fairways in Pennsylvania. Plant Dis. 83:783.

21. Valent, B., Farrall, L., and Chumley, F. G. 1986. Genetic studies of fertility and pathogenicity in Magnaporthe grisea (Pyricularia grisea). Iowa State J. Res. 60:569-594.

22. Vincelli, P. 1999. Gray leaf spot, an emerging disease of perennial ryegrass. Turfgrass Trends. 7(6):1-8.

23. Yaegashi, H., and Udagawa, S. 1978. The taxonomical identity of the perfect state of Pyricularia grisea and its allies. Can. J. Bot. 56:180-183. 